\title{
Can Retail Selling Prices of Petrol and Diesel Trigger Inflation in Malaysia?
}

\author{
Mohd Shahidan Shaari, Afifah Hanani Yusuf, Aidanazima Abashah and Tan Lee Pei
}

\begin{abstract}
Previously, many studies explored the effects of oil price on inflation by using the price of crude oil as the proxy of oil price. The novelty of this current study is that it used several types of fuel prices including RON95, RON97 and Diesel. This study employed the ARDL approach and analysed the monthly data from 2010 to 2015 in Malaysia. The result shows that there are significant effects of the price of RON95, RON97 and diesel on inflation in the long run in Malaysia. However, in the short run, the price of RON97 does not affect inflation while the prices of RON95 and diesel do affect inflation in Malaysia.
\end{abstract}

\section{Introduction}

The uncertainty in oil prices has attracted a large number of researchers to explore the effects of oil prices on economy such as inflation. Some ascertained that higher oil prices can have negative impacts and some discovered that higher oil prices can have positive impacts especially for oil producing countries.

Oil prices are inextricably related to the cost of production. Therefore, the rising oil price can lead to an increase in the cost of production. Higher oil prices can hike the costs of raw materials up, thus suppliers should adjust their price of goods so that they can maintain their profits [5]. As a result, the cost of increasing oil will be incurred by consumers and thus causing inflation. Sovuthea [22] stated that a rise in oil price results in inflation. Alem and Soderbom, [1] added that countries with higher oil price might face inflation. Therefore, governments should play an important role in controlling the price.

Most previous studies were only concerned about the relationship between oil price and inflation and used the price of crude oil as a proxy of oil prices [4, 23]. However, this current study uses RON95, RON97 and diesel prices as the proxy of oil prices instead of aggregate oil price to examine the effects of the retail selling petrol and diesel prices on inflation in Malaysia. Petrol is largely consumed by households for various activities. Petrol can be split into several types; RON95 and RON97. Households usually use these types of petrol for their vehicles. Diesel is another petroleum product which has the same function as that of petrol. However, its use is limited to only certain transports such as lorry and bus. All these petroleum products are indispensable for not only domestic economy, but also world economy [21]. Due to the importance of the commodity, many economists agreed that subsidizing petroleum price can shield economy from deleterious impacts of higher petroleum prices.

Since many issues arose due to an increase in oil price, some countries such as Malaysia subsidized petroleum prices. Nevertheless, in order to ensure its financial stability and 
improve its economic efficiency, the Malaysian government removed subsidies from this commodity. The reduction in the subsidy on oil triggered indignation among oil consumers. Most people suffered from the cost of increasing oil price. The rising prices for RON95, RON97 and diesel in Malaysia caused many people including economists to cast aspersions on it.

Fig.1 shows the price of RON95, RON97 and diesel in Malaysia from 2008 to 2015. In June 2008, the price of RON97 went up from RM1.92 to RM2.70 per litre. Therefore, to reduce the government's expenditure, the Malaysian government decontrolled the price of RON95 and RON97 starting from $1^{\text {st }}$ November 2008. The sharp rise in petrol price resulted in inflation for all consumer products (Shaari et al., 2012). The increasing trend was exhibited for RON97 with an increase of $41 \%$ over the period of September 2009 to May 2011. In July 2010, the government of Malaysia announced that the price of RON97 was determined by the global oil price (The Central Bank of Malaysia, 2011). This led to an increase of 25 cents per litre in the price of RON97 in Malaysia. Furthermore, the oil subsidy revision in Malaysia was implemented on December 4, 2010, causing a reduction of $5 \%$ in the subsidy for RON95. Thus, the price of RON97 increased by 50 cents to RM2.80 per litre from January to July, 2011. However, the price of RON97 grew sharply at the rate of $15.38 \%$ from RM2.60 per litre in July 2012 to RM3.00 per litre in September 2012 due to the hike of the world's oil price in the market. Furthermore, the price of RON97 increased from RM2.70 in August, 2013 to RM2.85 in September, 2013. However, the increase in the price of RON97 was lower than the increase in the price of RON95 and diesel in 2013 due to the increasing supply of oil in the world market from the OPEC member countries [11]. The reduction in the subsidy for RON95, RON97 and diesel aggravated the burden for Malaysian especially the low-income group. Hence, to reduce the burden for those in the low-income group, the Malaysian government announced the BR1M (Bantuan Rakyat 1Malaysia), a program that was introduced to curb the increasing cost of living pressures experienced by low-income group in 2010 [10].

Since mid-2014, the global oil price dropped by $50 \%$ due to surge in oil supply and a weak demand [15]. To enhance the country's revenue and to take advantage of the lowest oil price, the government of Malaysia has officially ended the subsidy of all fuels including RON95, RON97 and diesel on $1^{\text {st }}$ December 2014. Nonetheless, the elimination of subsidy for RON95, RON97 and diesel has affected most Malaysians financially. The inflation rate in 2015 was affected by the implementation of the new pricing mechanism for petrol prices in which there was an influence of global oil price volatility into domestic prices that had affected the domestic fuel products in Malaysia [13]. Fluctuation of oil prices kept happening starting from January to December 2015. 


\section{Prices of RON95, RON97 and Diesel in Malaysia}

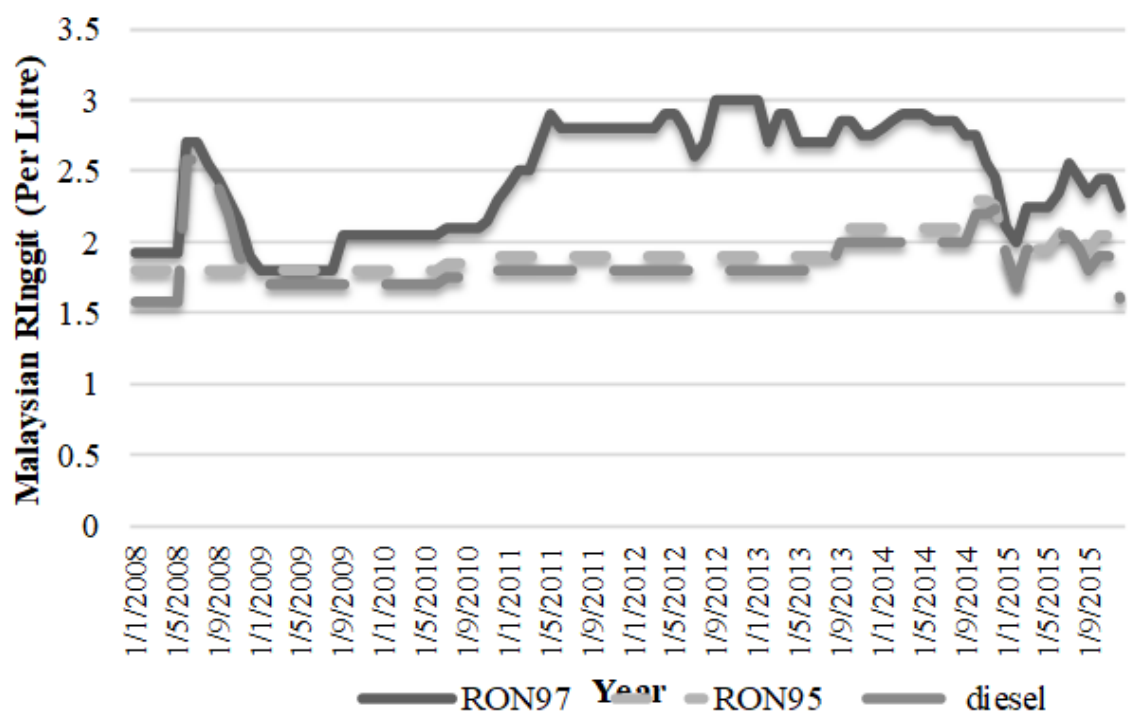

Fig. 1: Prices of RON95, RON97 and diesel in Malaysia.

(Source: Ministry of Domestic Trade, Co-operatives and Consumerism, 2016)

\section{Literature Review}

Numerous studies on examining the effects of oil price on inflation have produced mixed findings [24, 4,] and Taghizadeh Hesary, 2014. However, their findings were not consistent with some other studies that found a positive effect of oil price on inflation $[2,14,17]$. A limited number of previous studies found that there is no correlation between oil price and inflation $[20,15,3]$. The inconsistency were due to different economic conditions. In China [24] analysed the impact of oil price shocks on inflation from 1990 until 2013. Using the model of New Area-Wide and Dynamic Stochastic General Equilibrium, the study found that oil supply shocks can cause inflation in China, especially in the short run. [16] investigated the impact of global oil prices changes on consumer and producer prices separately from 1990 to 2012 in Turkey. The study found that the impact of oil price shocks on producer prices was two times higher than the impact on consumer prices.

Celik and Akgul [14] also studied the relationship between changes in fuel oil price and consumer price index in Turkey. The study used the Vector Error Correction Model to investigate the linkage between oil price shock and inflation in Turkey from 2005 until 2010. The study found that price fluctuations created by the distribution firms were adjusted to the price in order to suit the developments in the international oil market. Using the Vector Error Correction Model to analyse the data, the result indicated that a $1 \%$ increase in fuel oil prices will automatically increase the price of consumer index by $1.26 \%$. Besides, the study also found that an increase in fuel oil prices has increased the consumer price index in Turkey.

Jiranyakul [19] estimated the linkage between oil price shocks (nominal oil price) and domestic inflation (consumer price index and industrial production index) in Thailand for the period of 1993 to 2013. Using the Autoregressive Distributed Lag (ADDL) model, Error Correction estimation, Constant Conditional Correlation (ccc-GARCH) and Granger 
Causality test, the study found that domestic oil price shocks can cause inflation to rise. Oil price uncertainties do not cause inflation in the long run.

In a study by Chou and Tseng [15] on the effects of oil price on Taiwan's inflation rate (food, clothing, accommodation, transportation, medicine and health, education and leisure, and miscellaneous) for the period of 1982M3 to 1992M2, they have concluded that passthrough effect of oil prices on inflation is not significant in the short run (except for accommodation). The results also indicated that there is a significant effect of global oil prices shocks on Taiwan's consumer price index in the long run.

Alvarez et al. [3] analysed the impact of oil price shocks on consumer price inflation in Spain, Germany, France and Italy. Using the Linear and Nonlinear Model, Dynamic Stochastic General Equilibrium and Bank of Spain's Quarterly Model (MTBE) for the period of 1997 to 2007, the study discovered that there is a limited impact of oil price shocks on consumer price inflation in Spain, Germany, France and Italy. Nevertheless, the impact of oil price shocks on inflation in Spain is higher than that in Germany, France and Italy due to the diminishing share of indirect taxes in Spain.

\section{Methodology}

This study aims to examine the effects of retail selling petrol and diesel prices on inflation in Malaysia. An empirical analysis on the variables is conducted. Monthly data from 2010 to 2015 were collected to determine the effects of petroleum price on inflation. All the data were extracted from the Central Bank and the Ministry of Domestic Trade, Cooperative and Consumerism.

$$
\begin{aligned}
& \text { CPI }_{\mathrm{t}}=\beta_{0}+\beta_{1} \mathrm{M3}_{\mathrm{t}}+\beta_{2} \text { RON95 }_{\mathrm{t}}+ \\
& \beta_{3} \text { RON97 }_{\mathrm{t}}+\beta_{4} \text { DIESEL }_{\mathrm{t}}+\varepsilon_{\mathrm{t}}
\end{aligned}
$$

Whereas CPI is consumer price index, t refer to year, ${ }^{\beta}$ is coefficient, M3 is money supply, RON5 is the price of petrol for RON95, and RON97 is the price of petrol for RON97. DIESEL is the price of diesel and $\varepsilon$ is an error. In this study we include the money supply as a controlled variable. Unit root test was conducted to determine the stationary series in the level and in the first difference test based on the augmented Dickey-Fuller (ADF). The variable series is stationary or does not have a unit root; implying the alternative hypothesis is accepted and the null hypothesis is rejected. If the stationary test is not significant, suggesting that the variable series is non-stationary, the variable has a unit root (null hypothesis is accepted). The hypothesis in this test is presented as follows:

H0: $\delta=0$ (have a unit root test / not stationary)

H1: $\delta \neq 0$ (no unit root test / stationary) 
If the value of the t-statistic is larger than the critical value of the ADF and PP, the null hypothesis is accepted (unit root test exists). If the t-statistic is lower than the critical value of the ADF and PP, I does not have the unit root (the alternative hypothesis is accepted). First, the unit root test was conducted in level (unit root test in level with constant and unit root test in level with constant and trend). Then, the unit root test was performed in the first difference (unit root test in first difference with constant and unit root test in first difference with constant and trend). Equation 3, 4, and 5 express the equations in level without constant and trend, in level with constant only, and with constant and trend, respectively.

$$
\begin{aligned}
& \Delta Y_{t}= \\
& \alpha_{0}+\sum_{i=1}^{a} \emptyset_{1} Y_{t-1}+\sum_{j=1}^{b} \theta_{j} \Delta Y_{t-1}+\varepsilon_{t}
\end{aligned}
$$

Without constant and trend:

$$
\Delta \mathrm{Y}_{\mathrm{t}}=\delta \mathrm{Y}_{\mathrm{t}-1}+\mu_{\mathrm{t}}
$$

With constant:

$$
\Delta Y_{t}=\alpha+\delta Y_{t-1}+\mu_{t}
$$

Constant and trend:

$$
\Delta \mathrm{Y}_{\mathrm{t}}=\alpha+\beta \mathrm{T}+\delta \mathrm{Y}_{\mathrm{t}-1}+\mu_{\mathrm{t}}
$$

The co-integration technique of autoregressive distributed lag (ARDL) is employed to determine the order of co-integration of each variable. The advantage of this technique lies in the fact that it obviates the need to classify variables into $\mathrm{I}(1)$ or $\mathrm{I}(0)$. Each equation must be estimated by employing ordinary least square (OLS) approach. Then Wald test (Fstatistic) is calculated to discern the long run relationship among the variables. Applying the assumptions by Pesaran et al. (2001) in case III (intercept and trend), the equation for the relationship between dependent variable and independent variables is as follows:

$$
\begin{aligned}
& \text { CPI }_{\mathrm{t}}=\beta_{0}+\beta_{1} \text { CPI }_{\mathrm{t}-1}+\beta_{2} \mathrm{M}_{\mathrm{t}-1}+ \\
& \beta_{3} \text { RON95 }_{\mathrm{t}-1}+\beta_{4} \text { RON97 }_{\mathrm{t}-1}+ \\
& \beta_{5} \text { DIESEL }_{\mathrm{t}-1}+\beta_{6, \mathrm{i}} \sum_{\mathrm{i}=1}^{\mathrm{p}} \Delta \mathrm{CPI}_{\mathrm{t}-\mathrm{i}}+ \\
& \beta_{7, \mathrm{i}} \sum_{\mathrm{i}=1}^{\mathrm{q} 1} \Delta \mathrm{M}_{\mathrm{t}-\mathrm{i}}+\beta_{8, \mathrm{i}} \sum_{\mathrm{i}=1}^{\mathrm{q} 2} \Delta \mathrm{RON}_{\mathrm{t}-\mathrm{i}}+ \\
& \beta_{9, \mathrm{i}} \sum_{\mathrm{i}=1}^{\mathrm{q}} \Delta \text { RON97 }_{\mathrm{t}-\mathrm{i}}+ \\
& \beta_{10, \mathrm{i}} \sum_{\mathrm{i}=1}^{\mathrm{q} 4} \Delta \text { DIESEL }_{\mathrm{t}-\mathrm{i}}+\beta \mathrm{U}_{\mathrm{t}}
\end{aligned}
$$


Whereas $\Delta$ is the first level of differentiation as described in the logarithm. Other than that, equation (6) can also be considered as ARDL model. For the selection of lag in this study, the Akaike's Information Criterion (AIC) is referred. Wald test is also used to calculate the F-statistic. This is to confirm the existence of the long run relationships among variables. So, the hypothesis of the Wald test is as follows:

$\mathrm{H}_{0}: \beta_{1}=0$ and $\beta_{2}=\beta_{3}=\beta_{4}=0$

(No relationship in long run)

$$
\mathrm{H}_{1}: \beta_{1} \neq 0 \text { and } \beta_{2} \neq \beta_{3} \neq \beta_{4} \neq 0
$$

(There is a relationship in long run)

Then, the boundaries test is conducted by comparing F-statistic with critical value (according to the Pesaran schedule/table). If the F-statistic is lower than the critical value, the hypothesis $\mathrm{H}_{0}$ will be accepted at a certain significance level. The error correction model can be defined in the ARDL framework as follows:

$$
\begin{aligned}
& \mathrm{CPI}_{\mathrm{t}}=\mu+\sum_{\mathrm{i}=1}^{\mathrm{p}} \emptyset_{\mathrm{i}} \Delta \mathrm{CPI}_{\mathrm{t}-\mathrm{i}}+ \\
& \sum_{\mathrm{j}=1}^{\mathrm{q}=1} \varphi_{\mathrm{j}} \Delta \mathrm{M}_{\mathrm{t}-\mathrm{j}}+ \\
& \sum_{\mathrm{m}=1}^{\mathrm{q}=2} \gamma_{\mathrm{m}} \Delta \mathrm{RON} 5_{\mathrm{t}-\mathrm{m}}+ \\
& \sum_{\mathrm{p}=1}^{\mathrm{q}=3} \eta_{\mathrm{p}} \Delta{\text { RON } 97_{\mathrm{t}-\mathrm{p}}+}^{\sum_{\mathrm{g}=1}^{\mathrm{q}=4} \kappa_{\mathrm{g}} \Delta \text { DIESEL }_{\mathrm{t}-\mathrm{s}}+\text { vecm }_{\mathrm{t}-1}+\varepsilon_{\mathrm{t}}}
\end{aligned}
$$

Where $\emptyset, \varphi, \gamma, \eta$, and $\kappa$ in equation (7) refers to short-term dynamic coefficient and vecm indicates the speed of adjustment for the model (1) above.

\section{Finding}

Unit Root Results: Results from the Unit Root test shows that all the variables are not stationary at level for intercept, and intercept and trend. However, the variables become stationary at the first difference for intercept, and intercept and trend. Therefore, ARDL test can be conducted to see the long-run and short-run effects of retail selling prices of petrol and diesel on inflation.

Table 1: Unit Root Results

\begin{tabular}{|l|l|l|l|l|}
\hline \multicolumn{3}{|l|}{} & Intercept & \multicolumn{2}{l|}{ Intercept and Trend } \\
\hline Variables & Level & First Difference & Level & First Difference \\
\hline M3 & 0.936171 & $9.718928^{*}$ & 1.410553 & $9.731209^{*}$ \\
& $(0.7711)$ & $(0.0000)$ & $(0.8496)$ & $(0.0000)$ \\
\hline R97 & 1.833817 & $7.256789^{*}$ & 1.488713 & $7.490991^{*}$ \\
& $(0.3615)$ & $(0.0000)$ & $(0.8245)$ & $(0.0000)$ \\
\hline R95 & 2.819971 & $9.718928^{*}$ & 1.410553 & $9.731209^{*}$ \\
\hline
\end{tabular}




\begin{tabular}{|l|l|l|l|l|}
\hline & $(0.0605)$ & $(0.0000)$ & $(0.8496)$ & $(0.0000)$ \\
\hline DS & 2.458855 & $7.2768^{*}$ & 2.405163 & $7.329222^{*}$ \\
& $(0.1299)$ & $(0.0000)$ & $(0.3735)$ & $(0.0000)$ \\
\hline CPI & 0.375964 & $-8.024582^{*}$ & -2.639825 & $-5.547181^{*}$ \\
& $(0.9805)$ & $(0.0000)$ & $(0.2647)$ & $(0.0001)$ \\
\hline
\end{tabular}

Note: $*$ and $* *$ represent significant level at $1 \%$ and $5 \%$, respectively.

ARDL Results: The Bound test was conducted to see whether there is a long-run relationship between retail selling prices of petrol and diesel prices, and inflation in Malaysia. Results from the Bound test show that F-statistic is higher that upper bound and therefore, it can prove that there is an existence of the long-run relationship. Therefore, we can proceed to the ARDL approach to see which price can affect inflation.

Table 2: Bounds Test for the Existence of a Long Run Relationship

\begin{tabular}{|l|l|l|}
\hline \multicolumn{3}{|c|}{ F-statistic } \\
\hline \multicolumn{3}{|c|}{6.047937} \\
\hline \multicolumn{3}{|c|}{ Critical value } \\
\hline $1 \%$ significant level & Lower & Upper \\
\hline $5 \%$ significant level & 3.47 & 4.06 \\
\hline $\begin{array}{l}10 \% \text { significant } \\
\text { level }\end{array}$ & 4.40 & 4.57 \\
\hline
\end{tabular}

Notes: Critical value bounds obtain from Pesaran et al (2001), table CI (V) case V: Unrestricted intercept and unrestricted trend.

The Diagnostic and stability tests were performed to determine the goodness of the ARDL model. Table 3 and Fig. 2 and 3 for CUSUM and CUSUMQ tests are presented. The results suggest that the model pass the Breusch-Godfrey Serial Correlation LM test, Ramsey RESET stability test and ARCH test in the first stage. Therefore, there is no evidence of autocorrelation, no serial correlation and heteroscedasticity. Then, the cumulative sum of recursive residual (CUSUM) and the cumulative sum of squares of recursive residual (CUSUMSQ) are presented. The plots for both the CUSUM and CUSUMQ are within the boundaries. Therefore, it can be concluded that there is a stability in the ARDL models.

Table 3: Diagnostic Tests

\begin{tabular}{|c|c|}
\hline Test statistic & F-statistic \\
\hline A: Breusch-Godfrey Serial Correlation & 1.0958 \\
\hline B: Ramsey RESET stability & 1.8401 \\
\hline C: ARCH & 0.54298 \\
\hline
\end{tabular}

A: Langrange multiplier test of residual serial correlation

B: Functional Form

C: Heteroscedasticity 
Plot of Cumulative Sum of Recursive Residuals

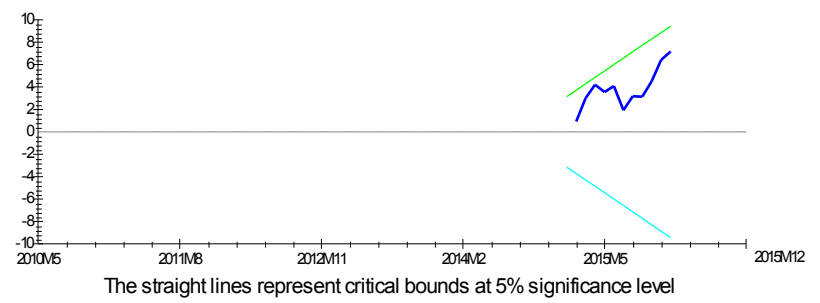

Fig. 2: Cumulative Sum of Recursive Residuals

\section{Plot of Cumulative Sum of Squares of Recursive Residuals}

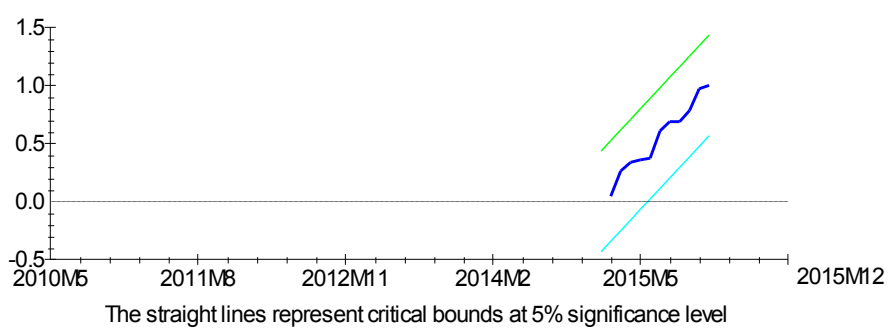

Fig. 3: Cumulative Sum of Squares of Recursive Residuals

The long-run coefficients of the variables under investigations are shown in the Table 4. The result shows that all the independent variables have effects on inflation in the long run. An increase in money supply can cause inflation in the long run. The price of RON97 can affect inflation positively in the long run. Therefore, a rise of 1 unit in the price of RON97 can increase inflation by 0.64261 . The results also show that there is a significant effect of the price of RON95 on inflation in the long run. Thus, the price of RON95 changes by 1 unit can cause inflation to change by 7.59. The price of diesel can also influence inflation negatively in the long run. Therefore, an increase of 1 unit of the price of diesel will lead to a reduction of -2.9130 in inflation.

Table 4: Estimated Long run Coefficients Using the ARDL Approach

\begin{tabular}{|l|c|c|c|}
\hline Regressor & Coefficient & $\begin{array}{c}\text { Standard } \\
\text { Error }\end{array}$ & T-ratio \\
\hline DM3 & 0.00001 & 0.000004 & $2.9619[.005]^{*}$ \\
\hline DR97 & 0.64261 & 0.29672 & $2.1657[.035]^{* *}$ \\
\hline DR95 & 7.5895 & 1.2769 & $5.9436[.000]^{*}$ \\
\hline DDS & -2.9130 & 1.1683 & $-2.4934[.016]^{* *}$ \\
\hline C & & & \\
\hline
\end{tabular}

Notes: *, and **indicate significant at $1 \%$, and $5 \%$ significant level. 
Table 5 shows results from the error correction representation for the selected ARDL Model test. The result shows that both money supply and RON97 does not positively and significantly affect inflation in the short run. However, the price of RON95 and diesel can affect inflation in the short run. An increase of 1 unit of the price of RON95 and diesel will lead to a rise of 5.38 and a decrease of -2.44 in inflation, respectively. Furthermore, the result also shows that the R-Squares of this study is high which is at $92 \%$, whereby the dependent variable can be explained by all independent variables by $92 \%$, and the DWstatistic is 1.7345 which is close to 2 .

Table 5: Error Correction Representation for the Selected ARDL Model

\begin{tabular}{|c|c|c|c|}
\hline Regressor & Coefficient & Standard Error & T-Ratio[Prob] \\
\hline dDM3 & 0.0000008 & 0.000002 & $0.50802[.613]$ \\
\hline dDR97 & 0.25481 & 0.18545 & $1.3740[.175]$ \\
\hline dDR95 & 5.3806 & 1.0483 & $5.1328[.000]^{*}$ \\
\hline dDDS & -2.4363 & 0.94998 & $-2.5646[.013]^{*}$ \\
\hline dC & 20.5787 & 6.5188 & $3.1568[.003]^{*}$ \\
\hline R-squared & \multicolumn{3}{|c}{} \\
\hline DW-statistic & 0.91541 & \\
\hline $\begin{array}{c}\text { Akaike Info. } \\
\text { Criterion }\end{array}$ & 37.7345 \\
\hline
\end{tabular}

\section{Conclusion}

This paper aims to investigate the effects of retail selling prices of petrol and diesel on inflation in Malaysia. The ADF unit root test was employed. All variables were found to be non-stationary in level and stationary in the first difference. Results from the long run coefficients using the ADRL approach shows that there are significant effects of retail selling prices of petrol and diesel in the long run. In the short run, the higher price of RON95 and Diesel can result in inflation in Malaysia. This study will be instrumental in the formulation of policies to ensure that inflation can be controlled in Malaysia. The Malaysian government should subsidize the price of RON95, RON97 and diesel to cushion its impacts. If the price was influenced by the world oil price, it might be detrimental to the general price in Malaysia.

\section{References}

1. Alem, Y., \& Soderbom, M., Household-Level Consumption in Urban Ethiopia: The Effects of a Large Food Price Shock. World Development, 40(1), 146-162, (2011) 
2. Alom, F., Economic Effects of Oil and Food Price Shocks in Asia and Pacific Countries: An Application of SVAR Model. In New Zealand Agricultural \& Resources Economics Society (pp. 1-43). Nelson: NZARES (2011)

3. Alvarez, L. J., Hurtado, S., Sanchez, I., \& Thomas, C., The Impact of Oil Price Changes on Spanish and Euro Area Consumer Price Inflation. Economic Modelling, 28(1-2), 422-431, (2010)

4. Belke, A., \& Dreger, C., The Transmission of Oil and Food Prices to Consumer Prices-Evidence for the MENA Countries. International Economics and Economic Policy, (2013)

5. Bolaji, B. O., \& Bolaji, G. A., Investigating the Effects of Increase in Oil Prices on Manufacturing Companies in Nigeria. Journal of Science and Technology, 11(2), 387-390, (2010)

6. Central Bank of Malaysia., Press Release Central Bank of Malaysia Annual Report 2008. Kuala Lumpur: Central Bank of Malaysia Publishing, (2009)

7. Central Bank of Malaysia., Central Bank of Malaysia Annual Report 2010. Kuala Lumpur: Central Bank of Malaysia Publishing, (2011)

8. Central Bank of Malaysia., Central Bank of Malaysia Annual Report 2011. Kuala Lumpur: Central Bank of Malaysia Publishing, (2012)

9. Central Bank of Malaysia., Central Bank of Malaysia Annual Report 2012. Kuala Lumpur: Central Bank of Malaysia Publishing, (2013)

10. Central Bank of Malaysia., Variations in Household Propensity to Consume Across Income Segments. Kuala Lumpur: Central Bank of Malaysia Publishing (2013)

11. Central Bank of Malaysia., Central Bank of Malaysia Annual Report 2013. Kuala Lumpur: Central Bank of Malaysia Publishing, (2014)

12. Central Bank of Malaysia., Price Reforms: Motivation, Impact and Mitigating Measures. Central Bank of Malaysia (Vol. 53). Kuala Lumpur: Central Bank of Malaysia Publishing (2014)

13. Central Bank of Malaysia., Central Bank of Malaysia Annual Report 2014. Kuala Lumpur: Central Bank of Malaysia Publishing (2015)

14. Celik, T., \& Akgül, B., Changes in Fuel Oil Prices in Turkey: An Estimation of the Inflation Effect Using VAR Analysis. Journal of Economics and Business, XIV(2), 11-21, (2011)

15. Chou, K. W., \& Tseng, Y. H., Pass-Through of Oil Prices to CPI Inflation in Taiwan. International Research Journal of Finance and Economics, 69, 73-83, (2011)

16. Dedeoglu, D., \& Kaya, H., Pass-Through of Oil Prices to Domestic Prices: Evidence from An Oil-Hungry but Oil-Poor Emerging Market. Economic Modelling, 43, 67-74, (2014)

17. Gichana, H. M., Relationship Between Crude Oil Prices and the Consumer Price Index in Kenya (Doctoral Diessertation, University of Nairobi), (2013)

18. Institute For Energy Research., 2014 Record Year for U.S. Oil Production; Largest Increase in Over 100 Years. Institute For Energy Research, (2015)

19. Ibrahim, M. H., \& Said, R., Disaggregated Consumer Prices and Oil Price Pass-Through: Evidence from Malaysia. China Agricultural Economic Review, 4(4), 514-529, (2012)

20. Jiranyakul, K., Oil Price Shocks and Domestic Inflation in Thailand. Available at SSRN 2578836, (2015)

21. Noordin, N. S. S., Oil Price Shock and Malaysian Sectoral Stock Market Return. Unpublished Masters in Business Administration Thesis, Faculty Business and Accountancy, University of Malaya, Kuala Lumpur, (2009) 
22. Sovuthea, H., Government Response to Inflation Crisis and Global Financial Crisis.CDRI, (2013)

23. Yoshino, N., \& Taghizadeh Hesary, F., Economic Impacts of Oil Price Fluctuations in Developed and Emerging Economies. IEEJ Energy Journal, 9(3), 58-75, (2014)

24. Zhao, L., Zhang, X., Wang, S. Y., \& Xu, S. Y., The Effects of Oil Price Shocks on Output and Inflation in China. Energy Economics, 1-10, (2014) 